Bryant University

Bryant Digital Repository

Management Department Journal Articles

Management Faculty Publications and

Research

$10-2012$

\title{
B2C Mass Customization in the Classroom
}

John K. Visich

Bryant University

Qiannong Gu

Sam Houston State University

Basheer M. Khumawala

University of Houston

Follow this and additional works at: https://digitalcommons.bryant.edu/manjou

\section{Recommended Citation}

Decision Sciences Journal of Innovative Education, volume 10 issue 4, 2012, pp. 521-545.

This Article is brought to you for free and open access by the Management Faculty Publications and Research at Bryant Digital Repository. It has been accepted for inclusion in Management Department Journal Articles by an authorized administrator of Bryant Digital Repository. For more information, please contact dcommons@bryant.edu. 


\title{
B2C Mass Customization in the Classroom \\ John K. Visich, Bryant University \\ Qian-nong Gu, Sam Houston State University \\ Basheer M. Khumawala, University of Houston
}

\begin{abstract}
The purpose of this paper is to describe an internet-based mass customization assignment in Operations Management/Supply Chain Management classes where students utilize the web site of a company that offers a customized product. Students evaluate the user interface, judge the value proposition of the product they demonstrate, and discuss issues of product design, process design and scheduling, inventory management, supply chain management, marketing, and competitors. The students learn about mass customization from both the producer's perspective and the consumer's perspective. Through their own research and the class presentations students are able to develop a better understanding of the implementation requirements and challenges of mass customization. The assignment is highly interactive and has been successfully used in Operations Management and Supply Chain Management courses at under-graduate and graduate levels and at multiple universities. In addition, practitioners interested in implementing a mass customization process can use the assignment as a brainstorming or benchmarking exercise.
\end{abstract}

Key words Mass Customization, Experiential Learning, Innovative Education, Operations Management, Supply Chain Management, Electronic Commerce

\section{Introduction}

The concept of mass customization was first introduced over two decades ago by Davis (1987) who described it as a production strategy that could provide variety to customers without significantly increasing the corresponding costs of mass production. Pine (1993) defined mass customization as "developing, producing, marketing and delivering affordable goods and 
services with enough variety and customization that nearly everyone finds exactly what they want." The objective of a mass customization strategy is to merge craft production of customized products with mass production of standard products in order to achieve low-cost product variety.

For manufacturers, a successfully implemented mass customization strategy provides competitive advantages via high customer service at a reasonable price (Senanayake and Little, 2010). Mass customization also provides benefits to consumers because they have a degree of control in ordering the product characteristics they want in their purchase. Customer satisfaction is a key to the success of mass customization implementation (Merle et al., 2010). New technologies are also integrated into mass customization to provide a user-friendly interface so consumers can easily view their product as they design it. For example, 3D technology is used to evaluate the fit of customized apparel (Apeagyei and Otieno, 2007).

The implementation of a mass customization strategy requires the coordination of multiple operational functions including order processing, scheduling, production, inventory management, packing, and distribution. Therefore, mass customization is an essential subject of Operations Management, which is a core course for business majors in most business schools. And, because of the coordination issues required for the delivery of raw materials inventory and the shipment of the finished product to the customer, mass customization is also applicable to Supply Chain Management courses. Though teaching mass customization in the classroom can be a challenge, some helpful resources are available for teaching mass customization more effectively. A wiki space teaching-operations-management has two in-class practices for teaching mass customization (see http://teaching-operations-management.wikispaces.com). One example uses Barbie dolls to represent the concept of customization, while the other uses mymuesli's website 
to show how customized products and standard production process can be integrated to achieve mass customization.

In this paper, we present an experiential learning assignment to introduce business students in Operation Management (OM) and Supply Chain Management (SCM) classes to real mass customization business practices in the manufacturing environment. In this assignment, student teams customize a product on a business-to-consumer (B2C) company's website. In their presentation and report the students are expected to discuss mass customization issues related to information technology, marketing, operations, and the supply chain. Experiencing the product customization process gives students a strong sense of how mass customization works and what the customer feels about a self designed product. Experiential learning can have a positive effect on a student's ability to gain and retain knowledge (Dewey, 1938). An experiential exercise in the classroom provides students with a hands-on experience and a visual impression of the topic they are studying, rather than merely hearing and thinking about the topic (Keeton and Tate, 1978). This experiential approach to teaching mass customization has been successfully used for under-graduate and graduate students and at multiple universities.

The rest of the paper is organized as the follows. In the next section, we briefly review the literature on mass customization and experiential learning. Then, we introduce the online mass customization assignment we use in class and discuss our teaching approach. Next, we present survey results on student perceptions of the assignment, and in the last section we discuss the class outcomes and the implications of our work for teachers and practitioners. 


\section{Literature Review}

Numerous studies have been conducted on the topics of mass customization and experiential learning. In this section we focus on those works we feel are most relevant to the assignment presented in Section 3.

\subsection{Mass customization applications}

Mass customization has been widely adopted in various manufacturing and service industries. For instance, the success of Dell Inc. is attributed not only to its pioneer move to an internetbased online ordering system, but also to allowing customers the option of 'building' their own computer (Falkenberg, 1998). In the apparel industry Levi-Strauss offers more than 10,000 variations on its custom-fitted jeans (Peppers and Rogers, 1998; Zipkin, 2001). In the service industry mass customization is used in Greece for mobile phone services such as the personalization of ring tones, phone interface and style, messaging options, and address books (Sigala, 2006). Al-Salim (2007) presented a data mining approach for the mass customization of travel packages in order to minimize operating costs while maximizing customer satisfaction with the package. Liou et al. (2010) illustrated dominance-based decision rules as a tool to help airlines eliminate unnecessary services and sell exclusive services to those passengers willing to pay for them. An empirical study by Goldsmith and Freiden (2004) of 608 adults in the United States found that consumer attitudes towards the purchase of mass customized products were favorable. Nearly half the respondents had purchased a personalized product and these younger, educated consumers were satisfied with their purchases.

\subsection{Mass customization benefits and challenges}


Ahlstrom and Westbrook (1999) surveyed forty manufacturing firms in the United Kingdom and found seven methods that can be used for mass customization: assembly of core modules, material processing, increase range of stock, make products self-customizing, information content modification, another company provides services around the product, and the retailer provides services around product. According to the authors the benefits of mass customization for manufacturers are: increased customer satisfaction, increased market share, increased customer knowledge, reduced order response time, reduced manufacturing cost, and increased profit.

The benefits of mass customization for consumers, on the other hand, were examined by Merle et al. (2010) who surveyed 231 students on the Nike ID program. The results showed two types of potential benefits for consumers: product and consumer preferences values. Product value includes utilitarian, uniqueness, and self-expressiveness. Consumer preferences value includes hedonic and creative achievement during the co-design process. Fiore et al. (2004) had previously reported similar findings from co-design customers for fashion products.

Because mass customization is only one of the ways to deliver variety, the implementation of a mass customization strategy needs to be carefully assessed. Market demand needs to exist, technology needs to be available and operational processes need to be designed. Successful implementation of a mass customization strategy requires a tight collaboration between marketing and product design teams. Zipkin (2001) discussed three main elements of mass customization: elicitation, process flexibility, and logistics. Elicitation is the mechanism for interacting with the customer and obtaining the correct product design information from the customer. Process flexibility is the production technology used to make the product according to the design criteria of the customer. Finally, logistics focuses on the tracking of the product 
through all processes from fabrication to customer delivery. Bardakci and Whitelock (2003) proposed a framework to determine whether consumers are ready for customization. Before committing to a mass customization strategy, manufacturers need to ask their customers three questions: 1) Are you willing to pay extra price?; 2) Are you willing to spend extra time?; and 3) Are you willing to wait a reasonable extra time to receive the order?. A longitudinal case study of six plants by Brown and Bessant (2003) explored the linkages between mass customization and agile manufacturing. The authors found that "a firm can have a manufacturing strategy without being agile, but it cannot become agile and pursue mass customization without having a manufacturing strategy in place" (p. 726). Senanayake and Little (2010) suggested five customization points for manufacturers. They are post-production customization point, fabrication customization point, fit customization point, feature customization point, and design customization point.

Other related research projects have also been conducted from various perspectives to support the implementation of mass customization. Duray (2002) conducted a study of manufacturing plants that practiced mass customization and was able to gather data from 126 mass customizers. She found that plants that matched the mass customized product line with the mass production product line had a higher level of financial performance than those plants that did not match product lines. Anderson-Connell et al. (2002) interviewed 70 potential customers to explore consumer preferences on mass customized apparel products. Consumers suggested four ways to customize apparel: clothes clones, totally custom, co-design, and design options with standard sizes. A survey of 303 members of the Society of Manufacturing Engineers by Tu et al. (2004) found customer closeness had a direct positive impact on mass customization capability. Customer closeness was defined as "the practice of keeping close contact with 
customers, to communicate with customers effectively, and to understand customers' individual needs" (p. 150). Liu et al. (2006) studied the effect of work-design practices on a company's mass customization capability. They identified three Sociotechnical Systems theory principles having distinct implications for mass customization: variance control; human values; and incompletion (work-design practices that focus on continuous improvement and learning). Endo and Kincade (2008) studied consumer behavior in an online shopping environment. They classified consumers into three groups: apathetic, ardent, and holistic consumers. This identification can help firms to effectively target potential consumers and maintain a long-term relationship. Finally, Ahmad et al. (2010) studied how product modularity and inter-functional design can foster mass customization capabilities.

\subsection{Experiential learning}

Kolb (1984, p. 41) defined experiential learning as "the process whereby knowledge is created through the transformation of experience. Knowledge results from the combination of grasping and transforming experience." Kolb and Kolb (2005, p. 194) extended this definition by addressing experiential learning as "a process of constructing knowledge that involves a creative tension...that is responsive to contextual demands". The traditional lecture environment in the classroom is no longer enough for students (Alic, 2008) and students as well as the companies these students will work for are pressuring business schools to pay greater attention to experiential learning (Li, Greenberg and Nicholls, 2007). Fortunately experiential learning is beneficially utilized in the business classroom, including courses in OM and SCM.

Numerous hands-on experiments and exercises have been developed and used to teach business graduate and undergraduate students a variety of production topics in Operations Management. For example, Fish (2005) developed a hands-on exercise with LEGO blocks, 
called "the running of the dogs", to teach students assembly line balancing. Students are given detailed instructions, with clear diagrams, on the assembly order and placement of the blocks. This experiential learning tool has been used successfully with over 900 undergraduate and graduate students at an AACSB accredited institution. Student feedback indicated that $95.6 \%$ (867 students) favored continued use of the exercise to facilitate learning, while only $1.1 \%$ (10) felt the exercise did not assist in learning and 3.3\% (30) were undecided Fish (2006) extended this LEGO blocks tool to effectively teach push and pull manufacturing concepts to undergraduate and graduate students. This 20 minute exercise was also well received by students with $92.3 \%$ (784 students) favoring its continued use to support learning. Kolenko (2011) developed a flashlight assembly project to introduce production operations and promote effective teamwork skills to new MBA students attending an on-campus orientation. The 1 hour exercise includes 10 minutes to read the instructions and answer questions, a 20 minute planning phase, 5 minutes for materials setup, a 10 minute build period, and 15 minutes for debriefing and disassembly. Survey results from 91 of 95 participating students indicated the exercise was wellreceived as it was voted the most popular of the four exercises conducted at the orientation, with $39 \%$ of the vote. And, the exercise was second for the survey question regarding which exercise they learned the most from, with $31 \%$ of the vote. Klotz (2011) has used a bicycle assembly line game for the past ten years in core operations management courses at the undergraduate, graduate and executive levels. This paper-based exercise facilitates learning through discovery as students are exposed to various production concepts such as output rate, capacity management and inventory through seven different line configurations that can be used to 'build' the same bicycle. The game is effective in helping students connect production rate with market demand. When the game is first played, fewer than $25 \%$ of the teams select an assembly line that meets 
market demand. But, after the game is played with inventory costs, more than $75 \%$ of the teams select the appropriate assembly line.

Several real-world projects with an appropriate level of difficulty and complexity have also been designed and used for experiential learning. Minch and Tabor (2007) founded an Internet Service Provider (ISP) business in 1996 as a hands-on project for network management classes. In the article the authors described how they used Merrill's principles of instruction to design the course, and how they initiated the class and gathered resources. Heriot et al. (2008) discussed the use of student consulting projects to facilitate experiential learning in a Production \& Operations Management course. A key aspect of the project is that student teams must approach a business and through investigation and applying principles learned in class, help the company improve some element of production or operations management. Umble et al. (2008) described the active learning "Edward Jones Challenges" where freshman students participated in six teambased competitions in six different core business courses. Some of the purposes supporting the challenges included the facilitation of hands-on learning, the reinforcement of key class concepts, and the connection of class concepts to the real world. In the article the authors discussed each challenge and developed 16 hypotheses on the pedagogical impact of the challenges. The most important conclusion the authors derived from their survey of students was that "complex unstructured projects are more effective than traditional academic analyses in enhancing all of the critical learning dimensions described in the literature review of this article." (p. 23). Visich et al. (2010) reported on the pedagogical impact of individual A3 process improvement projects for an Executive MBA class of health care professionals taking a course on Quality Management. Project outcomes indicated that the A3 method could be initiated by employees with basic training in lean and quality tools in a short period of time (less 
than 3 months). The authors also surveyed the students on the usefulness of the A3 method for problem solving in health care and developed ten propositions that could be tested or modified by future researchers. The design, teaching and management of two project-based courses that anchor a sustainability-focused MBA program are discussed by Sroufe and Ramos (2011). In their article the authors presented details on the solicitation of clients and projects, project scope and client deliverables, standards of professionalism for students, team assignment to projects, the selection of instructional resources, and the application of decision support technologies. They also discussed measures of course and program success, and the transferability of their curricula to institutions that do not have an existing sustainability program.

New forms of experiential learning are also introduced and examined in the recent literature. Arling et al. (2010) adopted an experiential case approach which combined the benefits of writing a case study and the benefits of sharing real-world experience. In this class project, students need to use their knowledge of system analysis and project management to identify and document business problems, and propose solutions based on a case study from Price Waterhouse Coopers.

Simulation has also proven to be an effective and efficient tool that can be used to simplify experiments so that students can grasp the key insights in a realistic business situation. Hoogeweegen et al. (2006) developed a multi-player business networking simulation game, to teach mass customization and product personalization. They applied the simulation game to the insurance industry, and a follow-up survey indicated that both students and industry managers confirmed the efficiency and effectiveness of this experiential learning tool. More recently, Piercy (2010) developed an in-class game to simulate manufacturing and ordering processes. 
The in-class assignment developed in this study adds to this body of literature. It provides a realistic alternative to OM and SCM faculties for teaching mass customization in an experiential setting.

\section{Mass Customization Assignment}

The mass customization assignment was first developed for a graduate elective course in Supply Chain Management to support a lecture on Coordinated Product and Supply Chain Design. In addition to Supply Chain Management courses, the assignment has also been successfully used in undergraduate and graduate core Operations Management courses and an undergraduate Global Dimensions of Operations Management course. This assignment utilizes an experiential approach where student teams demonstrate and discuss the mass customization of a product that can be designed and ordered through the internet. The assignment integrates aspects of information technology (IT), operations and marketing. For example, the user interface of the web site is critical to convey information to the customer and can be used to enhance marketing efforts in cross-selling profitable options. Both IT and marketing are connected to operations in that processes have to be coordinated in order to make the right product and then make sure the product is delivered to the right customer at the right time. These three areas within an organization can be discussed during the presentation and this reinforces the need for a systems approach when implementing a mass customization strategy.

\subsection{Assignment background material}

Prior to the introduction of the assignment a short lecture on mass customization is presented to the class. Topics include: the evolution of mass customization; key attributes of mass customization; mass customization and the supply chain; product variety versus product customization; and the requirements and challenges of mass customization. Next, the article 
"Offshoring Versus Spackling" (Cattani et al., 2005) is discussed to explain how make-to-order production of customized products can be smoothed with make-to-stock production of standard products. The article illustrates how textile manufacturer Timbuk 2 used a mass customization strategy to manufacturer personal carry bags (bicycle messenger bags, backpacks, etc.) domestically rather than offshoring the production. The trade-off Timbuk2 made was speed and customization versus cheap production costs. At the end of the article discussion, the Timbuk2 website (www.timbuk2.com) is shown and a student volunteer is requested to build a custom bag. That is, the student is asked to go through the virtual build process for the customized bag.

\subsection{In-class demonstration}

Before building a bag we discuss the clarity of the user interface of the website to support the elicitation element of mass customization (Zipkin, 2001 as discussed in Section 2.2). Next we instruct the student to click on the 'Build Your Own Bag' link and select a Laptop Messenger bag. This brings up a page where we can select one of three sizes and as the curser is scrolled over each size, the dimensions of the bag appear in the box on the right. We then use this bag size screen to discuss the ease of use and information characteristics a mass customization web

site should have. Once the student selects the bag size (suppose, medium) they are ready to build their unique bag. While the student builds their bag the instructor records each option and the number of choices for each option on the classroom blackboard. See Table 1 for the options and choices. During the build process the entire class gets involved by 'assisting' the builder with their design. This part of the demonstration can get interesting as students have their own ideas on what a bag should look like. At the end of the build process we discuss the accuracy of the order summary and then the student terminates the purchase process by going back to the home page. We then discuss the ease of use of the design process, the technologies used to convey 
relevant information on the bag to the customer, and the marketing of the accessories. We also compare the price of the custom bag with an on-line catalog bag and discuss the value proposition of the customized bag.

Next, we ask the class to multiply all of the option choices to determine the number of possible combinations: 3 panels $x 58$ panel fabrics $x 11$ bindings $x 32 \log$ os $x 12$ inside liners $x 3$ reflector styles $x 2$ bag sides $=4,409,856$ unique bags that could be designed. Students are often astounded at this number of choices for a simple bag. When accessory options are added, the possible combinations grow to $60,503,224,320(4,409,856$ x 49 strap pads x 72 -ways $\mathrm{x} 2$ beerdaleer x 5 dime bags x 4 shag bags). Note that the number of choices for an accessory includes the option of not selecting the accessory. We then discuss the inventory management issues to support so many combinations, and using an ABC analysis we identify which inventory items need to be carefully managed (panel fabrics are the most critical). During this discussion on inventory we remind the students that many of the raw materials can be used to build other types of bags as well. This now opens up very useful discussions around product design, process design, scheduling and tracking on the shop floor, and supply chain management.

\section{Insert Table 1 here}

\subsection{Teaching guidelines for the mass customization assignment}

After the bag building exercise is complete, the mass customization assignment is introduced. Appendix 1 shows the mass customization assignment requirements, while Appendix 2 illustrates the grading rubric used to evaluate the presentation and the written report. Both documents are made available to the students through the course web site (BlackBoard or Web

CT). Student teams are required to select a product they can customize on the web. All products must be approved by the instructor; therefore students submit to the instructor their company, the 
product to be customized, and the website link. This helps to 1) avoid redundant companies or products; 2) increase product diversity; and 3) ensure the product has a sufficient level of customization. For example, one team submitted a proposal for jewelry customizer Gemvara (www.gemvara.com), but the customization of earrings, rings and necklaces was limited mainly to changing stones in a pre-made (modular) setting. This is not mass customization. In order to qualify for the assignment, we require the product have at least five features that can be customized and each feature must have several options. The instructor approves the products on a first-come, first-approved basis and we have found this motivates the students to get to work quickly on their assignment. In addition, the students are encouraged to identify a product they are interested in and we do not make suggestions for products.

Once the students have selected their products, the instructor should emphasize the importance of doing additional research on the company or the industry the company competes in. Not surprisingly, we have found that undergraduate students need more encouragement to conduct outside research than did graduate students. Outside research can include visiting a car dealership (automobiles are a popular product selection), contacting the company by phone or email, or doing library/internet research. Most of the assignment requirements are loosely defined in order to allow the students flexibility in their presentation and report. This is because of the wide variety of products that can be mass customized as well as the different processes used to support the mass customization operations. For example, a team sweatshirt customized on the National Football League shop web site was compared to a similar product that could be purchased at the local Sports Authority store. Some of the apparel and footwear teams compared their product and its web site to competing on-line products. Timberland has a video that shows how a customized boot is made, and two videos were used for a presentation on Jostens Rings. 
Significant learning occurs during the presentations as students are exposed to a wide variety of user interfaces, marketing techniques, and operations processes. Therefore we recommend that prior to the presentations, the instructor virtually build each of the products the students will demonstrate in the classroom. This provides an opportunity for the instructor to fill in possible gaps or misconceptions and to add value to the student presentations. For example, the build of a Cadillac is not really customization since at the end of the process the customer is referred to a dealership that has a vehicle that most closely matches their design. On the other hand, the Toyota Scion has a much higher level of customization. Skateboards.com is not really a factory but a warehouse that distributes skateboards and parts to retailers. The customization of the skateboard occurs through a kitting process and the customer is given the option of assembling the skateboard themselves or having it done for them.

This assignment has been used in classes ranging from 35 students ( 7 teams of 5 students each) to 11 students ( 3 teams of 4,4 and 3 students). By carefully managing the products a rich learning environment can be created, even for small classes. During the summer of $2010 \mathrm{a}$ graduate Supply Chain Management class of three teams presented three uniquely different products: BMW (heavy industry - automobiles); Fine Cotton Company (light industry - apparel) and Me and Goji (food industry - cereal). All three teams enhanced their presentations with outside research. The BMW team contacted a local dealership and conducted library research. They found that the car would be custom made in Regensburg, Germany, that 75\% of the parts would be made in Germany, and that the lead time would be 45-60 days. The Fine Cotton Company team spoke with a sales and marketing manager who informed them that a major challenge was finding suppliers who "can live the mass customization." The Me and Goji team expanded their presentation with information on the company's sustainable operations efforts. A 
student in this class e-mailed the following comment: "We only had 3 presentations in our class, but we still managed to receive a great variety of mass customization perspective". See Table 2 for a list of companies and products that have been presented in several courses.

\section{Insert Table 2 here}

As shown in Appendix 2 the grading rubric assigns content points for both the presentation and the written report. For the presentation we focus mainly on the demonstration and a discussion of issues related to inventory management and supply chain management. A smooth virtual build indicates the students spent time on the web site learning about the different features and options. For inventory management we want the students to use an ABC analysis to identify which inputs are the most costly and which inputs can be used in other mass customized products the company offers. We then expect the students to discuss some of the more critical parts of the supply chain including key suppliers, availability of the inputs, and the transportation to the customer. In the written report we have the same expectations for inventory management and supply chain management as in the presentation. We also expect a detailed write-up on marketing and competitors. Our expectations are lower for product design, process design and scheduling because this information is much more difficult to obtain. However, students should at least discuss if the product has a modular or stand-alone design, if the process design is primarily assemble-to-order, make-to-order, or mass customization, and how the product might be scheduled relative to other products. We include all the items in the grading rubric in order to get students thinking about all the various issues and processes that are required to deliver a mass customized product using the internet as the communication portal. In addition, we have higher expectations for graduate students than undergraduate students and we expect graduate students to conduct additional research 
Our timeline for the assignment is to conduct the in-class demonstration about mid-way through the semester. At this point in time we will have covered (Operations Management core) or reviewed (Supply Chain Management elective) key concepts around product design, process choice, inventory management, and supply chain management basics. We schedule the presentations at the end of the semester, either during the last week of classes or during the final exam period.

\section{Student Perceptions of the Assignment and Propositions}

In order to assess student perceptions of the assignment in facilitating the teaching of mass customization we conducted a survey in the spring of 2011 across three sections of a Global Dimensions of Operations Management course. All 75 students were second semester sophomores who were studying in the International Business Program at a private university in the Northeast United States.

Students were required to attend class on the day of the presentations and the survey was distributed to students at the end of the presentations. The survey items were developed around the key deliverables of the assignment as outlined in the requirements and grading rubric in Appendices 1 and 2. Measurable survey questions utilized a 7-point Likert scale with $1=$ strongly disagree; 4 = neither agree nor disagree; 7 = strongly agree. We also collected stratification data on the gender and residency status of the student. See Appendix 3 for the survey items.

Table 3 shows the sample size, the average and the standard deviations for each survey question. Scores range from a high of 6.11 for the importance of inventory management in a mass customization strategy to a low of 5.63 for the Timbuk2 demonstration. However, a 2sample t-test did not indicate any significant differences between the scores for the survey 
questions. Other high scoring topics include the importance of technology and supply chain management in a mass customization strategy, and that the mass customization assignment was an experiential approach to learning. In addition, the group's mass customization report scored higher than the group's mass customization presentation. This is an interesting outcome given the widespread perception that students would rather make a presentation instead of write a report. As should be expected, the groups' report and presentation, as well as the presentations by the other groups all scored higher than Timbuk2 demonstration. Though the Timbuk2 demonstration had the lowest overall score, it is still an important element of the assignment. The Timbuk2 demonstration facilitates the setting of expectations for the deliverables and motivates students to ask questions about the assignment requirements. The results also show that students believe they were able to develop a better understanding of the different aspects of mass customization such as technology, ease of use of technology, marketing, product design, process design, scheduling, inventory management and supply chain management. This seems to indicate that students can see how the different elements need to be coordinated in order to implement a successful mass customization strategy. Based on these results we make the following five propositions regarding the mass customization assignment:

Proposition 1 (P1): The mass customization assignment helps students to develop a better understanding of mass customization.

Proposition 2 (P2): The mass customization assignment written report requirement helps students to develop a better understanding of mass customization.

Proposition 3 (P3): The mass customization assignment presentation requirement helps students to develop a better understanding of mass customization. 
Proposition 4 (P4): The mass customization assignment presentations by other groups help students to develop a better understanding of mass customization.

Proposition 5 (P5): The mass customization assignment was an experiential (active learning) assignment that facilitated a deeper understanding of mass customization.

\section{Insert Table 3 here}

\subsection{Statistical Analysis of Gender and Residency}

A number of studies have recently been conducted on gender differences for business students. Alfan and Othman (2005) investigated the performance of undergraduate students in the Faculty of Business and Accountancy at the University of Malaya, and found that female students performed better than male students. Whittingham (2006) found that gender-personality interactions had a significant effect on the academic performance of MBA students, while Yousef (2011) found no academic performance differences between genders in Operations Management courses at the United Arab Emirates University. Kaighobadi and Allen (2008) investigated a wide range of variables to identify academic success factors for undergraduate business students and found that female students tended to have a higher GPA than male students. However, student performance in earlier core course was found to be the strongest predictor of academic success. Finally, Albert and Johnson (2011) found little difference between genders in their perceptions of e-learning systems.

Educational issues and challenges for international students studying in business schools have also been studied in a wide variety of contexts. Woods et al. (2006) developed a training program to improve the skills of teachers who work with international students. The program 
covered four main areas: recognition of different teaching models, communication issues, increasing student participation, and assessment of student performance. Rijke and Plucker (2011) described their experiences educating international students and the problems they encountered. One of their recommendations to improve the success of international students is for instructors to use a variety of teaching approaches. A comparison of library and information skills of undergraduate United Kingdom and international students was conducted by VargaAtkins and Ashcroft (2004) who found no significant differences between the groups. However, international students had a more positive attitude towards library and information skills than domestic students. The use of group work in undergraduate courses to enhance learning outcomes was studied by Hunter et al. (2010) who found that international students had more difficulties engaging in group discussions than domestic students. And, this lack of participation was perceived by domestic students as a lack of accountability (termed 'social loafing') on the part of the international students. The authors then presented an intervention strategy to help all students develop the necessary skills to work in multicultural groups.

In order to determine if gender and residency had an effect on student perceptions of the assignment we conducted a set of two tests for each survey question: a variance test and a 2sample t-test. Using MiniTab we first conducted a variance test to see if we could pool the variances for the 2-sample t-test. The variance test reports the p-values from an F-test (normal distribution) and from a Levene's test (any continuous distribution), and if the p-values are greater than 0.05 we can assume the variances are equal and therefore can be pooled in the 2sample t-test. The 2-sample t-test was used because the samples are independent, and we attempted to pool variances because the 2-sample t-test with pooled variances is slightly more powerful than the two-sample t-test with unequal variances. 


\subsubsection{Gender}

Table 4 shows our results from the variance test and the 2-sample test for gender. Of the 75 students who filled out the survey, 35 indicated female and 35 male for their gender. Five students did not indicate their gender and these surveys were dropped from our analysis. For all 17 survey questions none of the variance tests were significant, hence we were able to pool the variances for the 2-sample t-test. In the 2-sample t-test, there were no significant differences between the genders for any of the survey items. The lowest p-value was 0.112 for "the importance of the ease of use of technology during the mass customization" where Females gave this question an average score of 6.20 while males scored it an average of 5.86. In addition, females scored the question "The mass customization assignment was an experiential (active learning) approach to learning." much higher than males (6.17 to 5.86), but the p-value of the 2sample t-test was only 0.202. Finally, males scored "the importance of a mass customization strategy in helping a firm attain a competitive advantage." higher than females (6.11 to 5.89), with $\mathrm{p}=0.339$. Based on these tests we make the following proposition:

Proposition 6 (P6): The mass customization assignment helps female and male students to develop a better understanding of mass customization.

\section{Insert Table 4 here}

\subsubsection{Residency}

The Global Dimensions of Operations Management classes had a strong representation of international students and this was very evident during one of the Timbuk 2 demonstrations when a student from Spain designed his bag in the colors of the Spanish flag. Spain won the World Cup in 2010 and this student was justifiably proud of his country's achievement - much to the chagrin of the soccer fans in the class from Argentina, China, Ecuador, Ghana and India. 
Therefore, we tested the data to see the if there were different learning perceptions for international students compared to students who were from the United States (US).

Table 5 shows the results of our tests based on residency, where 21 students indicated they were international students and 49 indicted they were not international students. The same five students who did not indicate their gender also did not indicate their residency and these surveys were dropped from our analysis. For 3 of the 2-sample t-tests were unable to assume the variances were equal and therefore these t-tests did not use a pooled variance (the p-values from the F-test and Levene's test are bolded). However, none of the 17 2-sample t-tests indicated perception differences between international and US students for the assignment.

International students gave an average rating of 6.29 compared to 5.98 for US students for the question "My groups' mass customization report helped me to develop a better understanding of mass customization.", with $\mathrm{p}=0.181$. International students scored the mass customization lecture higher than US students at 6.00 to $5.67(\mathrm{p}=0.160)$ indicating that they might not have been as aware of mass customization as US students. Several US students had discussed prior experiences with on-line mass customization, including NikeID and Apple's Mac Book. Finally, international students scored the survey item "The lecture, demonstration, report, and class presentations helped me to develop a better understanding of mass customization" at 6.14 to 5.88 $(\mathrm{p}=0.220)$. Based on the survey results, we make the following proposition:

Proposition 7 (P7): The mass customization assignment was effective in helping both international and US students develop a better understanding of mass customization.

Insert Table 5 here 


\section{Conclusion}

The mass customization assignment presented in this paper can be used to create an interactive learning environment in Operations Management and Supply Chain Management courses. Since the students have to demonstrate their product to their peers, they take the assignment seriously and this experiential aspect appears to enhance knowledge of mass customization. Several students have commented on the assignment either in an e-mail or on instructor evaluations. An undergraduate Global Dimensions of Operations Management student wrote "This assignment challenged me to think critically about all processes involved in mass customization. I was able to apply concepts I learned in the classroom to real world examples, the value of which is unmeasureable." A graduate student in Supply Chain Management commented "I really liked the way the project had to be done. Having a hand on and having to analyze the website gave me a good idea of what mass is customization and especially what processes and supply chain the company has to have to achieve a good customer service."

This assignment is not without limitations. Students, especially undergraduates, struggle with product design, process design and scheduling topics. The problem here is that information is not readily available on these topics for the companies the students select. Students need to be encouraged to either conduct research to try to find the answers or to apply concepts covered in class to match up with the product. A minor issue is the lack of a formal structure for the written report. However, this is done on purpose in order to provide flexibility due to the different supply chain and manufacturing characteristics of the various products.

Though the focus of the student requirements is on the processes to support the manufacturer of the customized product, the assignment also integrates information technology and marketing concepts. Therefore, an Information Technology or Marketing instructor could modify the 
assignment to focus on aspects of mass customization that are related to their areas. The assignment can also be used in an Industrial Engineering (IE) school curriculum. The above comment from the graduate student was from an IE student who took the Supply Chain Management course as an elective in the business school.

Although the mass customization assignment presented in this report is designed for use in the classroom, it can also be used by practitioners. The assignment requirements can be used as the basis for a brainstorming or benchmarking exercise by a company looking to implement a mass customization strategy. By investigating the technologies, marketing techniques and processes used by current mass customizers, a company can create user interfaces and business models that best fit the product line to be mass customized.

\section{References}

Ahlstrom, P. \& Westbrook, R. (1999). Implications of mass customization for operations management: An exploratory survey. International Journal of Operations and Production Management, 19(3), 262-274.

Ahmad, S., Schroeder, G.R. \& Mallick, N.D. (2010). The relationship among modularity, functional coordination, and mass customization: Implication for competitiveness. European Journal of Information Management, 13(1), 46-61.

Albert, L.J., \& Johnson, C.S. (2011). Socioeconomic status- and gender-based differences in students' perceptions of E-learning systems. Decision Sciences Journal of Innovative Education, 9(3), 421-436.

Alfan, E., \& Othman, M.N. (2005). Undergraduate students' performance: The case of University of Malaya. Quality Assurance in Education, 13(4), 329-343.

Alic, J.A. (2008). Technical knowledge and experiential learning: What people know and can do. Technology Analysis \& Strategic Management, 20(4), 427-442.

Al-Salim, B. (2007). Mass customization of travel packages: data mining approach. International Journal of Flexible Manufacturing Systems, 19(4), 612-624. 
Anderson-Connell, L.J, Ulrich, P.V. \& Brannon E.L. (2002). A consumer-driven model for mass customization in the apparel market. Journal of Fashion Marketing and Management, 6(3), 240-258.

Apeagyei, R.P. \& Otieno, R. (2007). Usability of pattern customizing technology in the achievement and testing of fit for mass customization. Journal of Fashion Marketing and Management, 11(3), 349-365.

Arling, A.P., Deeter, C. \& Eggers, H. (2010). A system analysis experiential case study: Repeatable real-world problem solving. Decision Sciences Journal of Innovative Education, $8(2), 417-422$.

Brown, S. \& Bessant, J. (2003). The manufacturing strategy-capabilities links in mass customisation and agile manufacturing - an exploratory study. International Journal of Operations and Production Management, 23(7/8), 707-730.

Cattani, K., Dahan, E. \& Schmidt, G. (2005). Offshoring versus “spackling”. Sloan Management Review, 46(3), 6-7.

Davis, S. (1987). Future Perfect. Reading, MA: Addison-Wesley.

Dewey, J. (1938). Experience and Education. New York: Macmillan Publishing Company.

Duray, R. (2002). Mass customization origins: Mass or custom manufacturing. International Journal of Operations and Production Management, 22(3), 314-328.

Endo, S. \& Kincade, H.D. (2008). Mass customization for long-term relationship development: Why consumers purchase mass customized products again. Qualitative Market Research: An International Journal, 11(3), 275-294.

Falkenberg, L. (1998). Virtually made to order. Money, 1(2), 60.

Fiore, A.M., Lee, S.E. \& Kunz, G. (2004). Individual differences, motivations, and willingness to use a mass customization option for fashion products. European Journal of Marketing, 38(7), 835-849.

Fish, A.L. (2005). Teaching assembly line balancing: A mini-demonstration with DUPLO blocks or 'the running of the dogs'. Decision Sciences Journal of Innovative Education, 3(1), 169176.

Fish, A.L. (2006). Push versus pull mini-demonstration: A continuation of the minidemonstration with Duplos or 'the running of the dogs-Part II'. Decision Sciences Journal of Innovative Education, 4(2), 323-330.

Goldsmith, E.R. \& Freiden, B.J. (2004). Have it your way: consumer attitudes toward personalized marketing. Marketing Intelligence \& Planning, 22(2), 228-239. 
Heriot, K.C., Cook, R., Jones, R.C. \& Simpson, L. (2008. The use of student consulting projects as an active learning pedagogy: A case study in a production/operations management course. Decision Sciences Journal of Innovative Education, 6 (2), 463-481.

Hoogeweegen, R.M., van Liere, W.D., Vervest, H.M.P., van der Meijden, L.H. \& de Lepper, I. (2006). Strategizing for mass customization by planning the business networking game. Decision Support Systems, 42(3), 1402-1412.

Hunter, J.D., Vickery, J. \& Smyth, R. (2010). Enhancing learning outcomes through group work in an internationalized undergraduate business education context. Journal of Management \& Organization, 16(5), 700-714.

Kaighobadi, M., \& Allen, M.T. (2008). Investigating academic success factors for undergraduate business students. Decision Sciences Journal of Innovative Education, 6(2), 427-436.

Keeton, M. and Tate, P. (1978), Learning by Experience-What, Why How, Hosse-Bass, San Francisco.

Klotz, D. (2011), “The bicycle assembly line game”, Decision Sciences Journal of Innovative Education, Vol.9 No.3, 371-377.

Kolb, D. A. (1984). Experiential Learning: Experience as a source of learning and development. Englewood Cliffs, NJ: Prentice Hall.

Kolb, Y.A. \& Kolb, D.A. (2005). Learning styles and learning spaces: Enhancing experiential learning in higher education. Academy of Management Learning and Education, 4(2), 193212.

Kolenko, T. (2011). Flashlight assembly challenge: introducing production operations to MBA students. Decision Sciences Journal of Innovative Education, 9(1), 75-79.

Li, T., Greenberg, B.A. \& Nicholls, J.A.F. (2007). Teaching experiential learning: Adoption of an innovative course in an MBA marketing curriculum. Journal of Marketing Education, 29(1), 25-33.

Liou, J.J.H., Yen, L. \& Tzeng, G.-H. (2010). Using decision rules to achieve mass customization of airline services. European Journal of Operational Research, 205(3), 680686.

Liu, G., Shah, R. \& Schroeder, R.G. (2006). Linking work design to mass customization: A sociotechnical systems perspective. Decision Sciences Journal, 37(4), 519-545.

Merle, A., Chandon, J., Roux, E. \& Alizon, F. (2010). Perceived value of the mass-customized product and mass customization experience for individual consumers. Production and Operations Management, 19(5), 503-514. 
Minch, P.R. \& Tabor, W.S. (2007). Achieving active learning with a student-run internet service provider business: the case of bsu.net. Decision Sciences Journal of Innovative Education, 5(1), 179-182.

Piercy, N. (2010). Experiential learning: The case of the production game. Decision Sciences Journal of Innovative Education, 8(1), 275-280.

Pine, B.J. II (1993). Mass customization: The new frontier in business competition, Boston, MA: Harvard Business School Press.

Rijke, P. de \& Plucker, J.A. (2011). Getting what we wish for: The realities of business education for a global economy. Business Horizons, 54(4), 375-382.

Sigala, M. (2006). Mass customization implementation models and customer value in mobile phones services. Managing Service Quality, 16(4), 395-420.

Senanayake, M.M. \& Little, J.T. (2010). Mass customization: Points and extent of apparel customization. Journal of Fashion Marketing and Management, 14(2), 282-299.

Sroufe, R. \& Ramos, D. (2011). MBA program trends and best practices in teaching sustainability: Live project courses. Decision Sciences Journal of Innovative Education, 9(3), 349-369.

Tu, Q., Vonderembse, M.A., Ragu-Nathan, T.S. \& Ragu-Nathan, B. (2004). Measuring modularity-based manufacturing practices and their impact on mass customization capability: A customer-driven perspective. Decision Sciences Journal, 35(2), 147-168.

Umble, E.J., Umble, M. \& Artz, K. (2008). Enhancing undergraduates' capabilities through team-based competitions: The Edward Jones Challenge. Decision Sciences Journal of Innovative Education, 6(1), 1-27.

Varga-Atkins, T. \& Ashcroft, L. (2004). Information skills of undergraduate business students a comparison of UK and international students. Library Management, 25(1/2), 39-55.

Visich, J.K., Wicks, A.M. \& Zalila, F. (2010). Practitioner perceptions of the A3 method for process improvement in health care. Decision Sciences Journal of Innovative Education, $8(1), 191-213$.

Whittingham, K.L. (2006). Impact of personality on academic performance of MBA students: Qualitative versus quantitative courses. Decision Sciences Journal of Innovative Education, 4(2), 175-190.

Woods, P.R., Jordan, P.J., Troth, A.C., Kerr, D. \& Loudoun, R. (2006). Effective teaching in the multicultural business classroom. Journal of Teaching in International Business, 17(4), 2748. 
Yousef, D.A. (2011). Academic performance of business students in quantitative courses: A study in the faculty of business and economics at the UAE University. Decision Sciences Journal of Innovative Education, 9(2), 255-267.

Zipkin, P. (2001). The limits of mass customization. MIT Sloan Management Review, 42(3), 8187.

Table 1. Timbuk2 Bicycle Messenger Bag

\begin{tabular}{|l|l|}
\hline Option & Choices \\
\hline Basic Bag & \\
\hline Panels & 3 \\
\hline Panel Fabrics (some fabrics cost an extra \$15 a panel) & 58 \\
\hline Binding & 11 \\
\hline Logo & 32 \\
\hline Inside Liner & 12 \\
\hline Reflector Style (\$10 extra for compression straps with tabs) & 3 \\
\hline Wear Your Bag? (left or right hand side) & 2 \\
\hline Total Basic Bag Combinations & $\mathbf{4 , 4 0 9 , 8 5 6}$ \\
\hline *Accessories & \\
\hline Strap Pads (4 types, maximum of 12 colors, \$10-\$20) & 49 \\
\hline 2Way (2 sizes, maximum of 3 colors, \$20) & 7 \\
\hline Beerdaleer (beverage holder, \$10) & 2 \\
\hline Dime Bag (4 colors, \$12) & 5 \\
\hline Shag Bag (3 colors, \$18) & 4 \\
\hline Total Accessory Combinations & $\mathbf{1 3 , 7 2 0}$ \\
\hline Total Combinations & $\mathbf{6 0 , 5 0 3 , 2 2 4 , 3 2 0}$ \\
\hline
\end{tabular}

*Accessory choices include the option of not selecting an accessory. 
Table 2. Mass Customization Projects

\begin{tabular}{|c|c|}
\hline Company or Brand & Industry and Product Demonstrated \\
\hline $\begin{array}{l}\text { AlienWare } \\
\text { www.alienware.com }\end{array}$ & $\begin{array}{l}\text { Computers } \\
\text { Area-51 desktop gaming computer }\end{array}$ \\
\hline $\begin{array}{l}\text { Apple } \\
\text { www.apple.com }\end{array}$ & $\begin{array}{l}\text { Computers } \\
\text { Mac Book Pro }\end{array}$ \\
\hline $\begin{array}{l}\text { BMW } \\
\text { www.bmw.com }\end{array}$ & $\begin{array}{l}\text { Automotive } \\
2010335 \text { i sedan }\end{array}$ \\
\hline $\begin{array}{l}\text { Colorware } \\
\text { www.colorwearpc.com }\end{array}$ & $\begin{array}{l}\text { Electronics } \\
\text { Custom colors for a Mac }\end{array}$ \\
\hline $\begin{array}{l}\text { Custom Ink } \\
\text { www.customink.com }\end{array}$ & $\begin{array}{l}\text { Apparel } \\
\text { T-shirt }\end{array}$ \\
\hline $\begin{array}{l}\text { Dell } \\
\text { www.dell.com }\end{array}$ & $\begin{array}{l}\text { Computers } \\
\text { Inspiron 15R Laptop }\end{array}$ \\
\hline $\begin{array}{l}\text { General Motors Cadillac } \\
\text { www.cadillac.com }\end{array}$ & $\begin{array}{l}\text { Automotive } \\
\text { CTS Coupe }\end{array}$ \\
\hline $\begin{array}{l}\text { Fine Cotton Company } \\
\text { www.finecottoncompany.com }\end{array}$ & $\begin{array}{l}\text { Apparel } \\
\text { Men's long sleeved dress shirt }\end{array}$ \\
\hline $\begin{array}{l}\text { Jostens Rings } \\
\text { Www.jostens.com }\end{array}$ & $\begin{array}{l}\text { Jewelry } \\
\text { Men's High School Class Ring }\end{array}$ \\
\hline $\begin{array}{l}\text { Longchamp } \\
\text { www.longchamp.com }\end{array}$ & $\begin{array}{l}\text { Apparel } \\
\text { Handbag }\end{array}$ \\
\hline $\begin{array}{l}\text { Me and Gogi } \\
\text { www.meandgoji.com }\end{array}$ & $\begin{array}{l}\text { Cereal, Granola and Muesli } \\
\text { Cereal }\end{array}$ \\
\hline $\begin{array}{l}\text { My Twinn } \\
\text { www.mytwinn.com }\end{array}$ & $\begin{array}{l}\text { Collectables } \\
\text { Doll that looks like you (girls) }\end{array}$ \\
\hline $\begin{array}{l}\text { National Football League (USA) } \\
\text { www.nflshop.com }\end{array}$ & $\begin{array}{l}\text { Apparel } \\
\text { NFL football team jerseys }\end{array}$ \\
\hline $\begin{array}{l}\text { NikeID } \\
\text { www.nikeid.com }\end{array}$ & $\begin{array}{l}\text { Footwear, Apparel, Sports Bags } \\
\text { Men's Air Jordan basketball shoe }\end{array}$ \\
\hline $\begin{array}{l}\text { Ralph Lauren } \\
\text { www.ralphlauren.com }\end{array}$ & $\begin{array}{l}\text { Apparel } \\
\text { Women's Polo shirt }\end{array}$ \\
\hline $\begin{array}{l}\text { Reebok } \\
\text { www.reebok.com }\end{array}$ & $\begin{array}{l}\text { Footwear } \\
\text { Women's Runtone shoe }\end{array}$ \\
\hline $\begin{array}{l}\text { Scion (Toyota Corporation) } \\
\text { www.scion.com }\end{array}$ & $\begin{array}{l}\text { Automotive } \\
\text { Scion tC }\end{array}$ \\
\hline $\begin{array}{l}\text { Skateboards.com } \\
\text { www.skateboards.com }\end{array}$ & $\begin{array}{l}\text { Sports Equipment } \\
\text { Skateboard }\end{array}$ \\
\hline $\begin{array}{l}\text { Smart Car } \\
\text { www.smartusa.com }\end{array}$ & $\begin{array}{l}\text { Automotive } \\
\text { Passion Cabriolet }\end{array}$ \\
\hline $\begin{array}{l}\text { Timberland } \\
\text { www.timberland.com }\end{array}$ & $\begin{array}{l}\text { Footwear } \\
\text { Men's Campus style boot }\end{array}$ \\
\hline
\end{tabular}


Table 3 Survey Sample Size, Average and Standard Deviation

\begin{tabular}{|c|c|c|c|}
\hline Survey Questions & Sample & Avg. & SD \\
\hline $\begin{array}{l}\text { The mass customization lecture helped me to develop a better } \\
\text { understanding of mass customization. }\end{array}$ & 75 & 5.80 & 0.89 \\
\hline $\begin{array}{l}\text { The mass customization demonstration of the Timbuk } 2 \text { bag helped me } \\
\text { to develop a better understanding of mass customization. }\end{array}$ & 75 & 5.63 & 1.30 \\
\hline $\begin{array}{l}\text { My groups' mass customization report helped me to develop a better } \\
\text { understanding of mass customization. }\end{array}$ & 75 & 6.03 & 0.94 \\
\hline $\begin{array}{l}\text { My groups' mass customization presentation helped me to develop a } \\
\text { better understanding of mass customization. }\end{array}$ & 73 & 5.89 & 0.98 \\
\hline $\begin{array}{l}\text { The mass customization presentations by other groups in the class } \\
\text { helped me to develop a better understanding of mass customization. }\end{array}$ & 74 & 5.77 & 1.04 \\
\hline $\begin{array}{l}\text { The lecture, demonstration, report, and class presentations helped me to } \\
\text { develop a better understanding of: }\end{array}$ & -- & --- & --- \\
\hline mass customization. & 75 & 5.95 & 0.82 \\
\hline the overall importance of technology in a mass customization strategy. & 75 & 6.05 & 0.97 \\
\hline $\begin{array}{l}\text { the importance of the ease of use of technology during the mass } \\
\text { customization steps in a mass customization strategy. }\end{array}$ & 75 & 6.01 & 0.92 \\
\hline the importance of marketing in a mass customization strategy. & 74 & 5.69 & 1.05 \\
\hline the importance of product design in a mass customization strategy. & 75 & 5.99 & 0.85 \\
\hline the importance of process design in a mass customization strategy. & 75 & 5.96 & 0.92 \\
\hline the importance of scheduling in a mass customization strategy. & 75 & 5.92 & 0.98 \\
\hline $\begin{array}{l}\text { the importance of inventory management in a mass customization } \\
\text { strategy. }\end{array}$ & 75 & 6.11 & 0.99 \\
\hline $\begin{array}{l}\text { the importance of supply chain management in a mass customization } \\
\text { strategy. }\end{array}$ & 75 & 6.03 & 1.08 \\
\hline $\begin{array}{l}\text { the importance of a mass customization strategy in helping a firm attain } \\
\text { a competitive advantage. }\end{array}$ & 75 & 6.01 & 1.01 \\
\hline $\begin{array}{l}\text { The mass customization Timbuk } 2 \text { demonstration was an experiential } \\
\text { (active learning) approach to learning. }\end{array}$ & 75 & 5.88 & 1.09 \\
\hline $\begin{array}{l}\text { The mass customization assignment was an experiential (active } \\
\text { learning) approach to learning. }\end{array}$ & 75 & 6.03 & 0.96 \\
\hline
\end{tabular}


Table 4 Survey Results for Gender

\begin{tabular}{|c|c|c|c|c|c|}
\hline \multirow[t]{2}{*}{$\mathrm{n}=70: 35$ Female and 35 Male } & \multicolumn{2}{|c|}{ Average } & \multicolumn{2}{|c|}{$\begin{array}{l}\text { Equal Variances Test } \\
\text { p-value }\end{array}$} & \multirow{2}{*}{$\begin{array}{c}\text { 2-Sample } \\
\text { t-test } \\
\text { p-value }\end{array}$} \\
\hline & Female & Male & F-test & Levene's & \\
\hline $\begin{array}{l}\text { The mass customization lecture helped me to develop a better understanding of } \\
\text { mass customization. }\end{array}$ & 5.80 & 5.74 & 0.922 & 0.695 & 0.790 \\
\hline $\begin{array}{l}\text { The mass customization demonstration of the Timbuk } 2 \text { bag helped me to } \\
\text { develop a better understanding of mass customization. }\end{array}$ & 5.63 & 5.51 & 0.634 & 1.000 & 0.714 \\
\hline $\begin{array}{l}\text { My groups' mass customization report helped me to develop a better } \\
\text { understanding of mass customization. }\end{array}$ & 6.06 & 6.09 & 0.925 & 0.841 & 0.892 \\
\hline $\begin{array}{l}\text { My groups' mass customization presentation helped me to develop a better } \\
\text { understanding of mass customization. }\end{array}$ & 5.91 & 5.94 & 0.781 & 0.849 & 0.898 \\
\hline $\begin{array}{l}\text { The mass customization presentations by other groups in the class helped me to } \\
\text { develop a better understanding of mass customization. }\end{array}$ & 5.80 & 5.76 & 0.331 & 0.785 & 0.889 \\
\hline $\begin{array}{l}\text { The lecture, demonstration, report, and class presentations helped me to develop } \\
\text { a better understanding of: }\end{array}$ & -- & --- & --- & --- & --- \\
\hline mass customization. & 5.91 & 6.00 & 0.401 & 0.304 & 0.667 \\
\hline the overall importance of technology in a mass customization strategy. & 6.14 & 6.00 & 0.832 & 0.358 & 0.534 \\
\hline $\begin{array}{l}\text { the importance of the ease of use of technology during the mass customization } \\
\text { steps in a mass customization strategy. }\end{array}$ & 6.20 & 5.86 & 0.108 & 0.218 & 0.112 \\
\hline the importance of marketing in a mass customization strategy. & 5.71 & 5.59 & 0.274 & 0.256 & 0.623 \\
\hline the importance of product design in a mass customization strategy. & 5.94 & 6.00 & 0.989 & 0.641 & 0.777 \\
\hline the importance of process design in a mass customization strategy. & 5.94 & 5.97 & 0.761 & 0.553 & 0.898 \\
\hline the importance of scheduling in a mass customization strategy. & 5.97 & 5.80 & 0.268 & 0.275 & 0.471 \\
\hline the importance of inventory management in a mass customization strategy. & 6.17 & 6.00 & 0.103 & 0.266 & 0.479 \\
\hline the importance of supply chain management in a mass customization strategy. & 5.97 & 6.09 & 0.898 & 0.713 & 0.660 \\
\hline $\begin{array}{l}\text { the importance of a mass customization strategy in helping a firm attain a } \\
\text { competitive advantage. }\end{array}$ & 5.89 & 6.11 & 0.297 & 0.468 & 0.339 \\
\hline $\begin{array}{l}\text { The mass customization Timbuk2 demonstration was an experiential (active } \\
\text { learning) approach to learning. }\end{array}$ & 5.83 & 5.89 & 0.517 & 0.375 & 0.831 \\
\hline $\begin{array}{l}\text { The mass customization assignment was an experiential (active learning) } \\
\text { approach to learning. }\end{array}$ & 6.17 & 5.89 & 0.208 & 0.394 & 0.202 \\
\hline
\end{tabular}


Table 5 Survey Results for Residency

\begin{tabular}{|c|c|c|c|c|c|}
\hline \multirow[t]{2}{*}{ Survey Question $\quad n=70: 21$ International and 49 USA } & \multicolumn{2}{|c|}{$\begin{array}{c}\text { International } \\
\text { Student? Y/N } \\
\text { Average }\end{array}$} & \multicolumn{2}{|c|}{$\begin{array}{l}\text { Equal Variances Test } \\
\text { p-value }\end{array}$} & \multirow[t]{2}{*}{$\begin{array}{c}\text { 2-Sample } \\
\text { t-test } \\
\text { p-value }\end{array}$} \\
\hline & Yes & No & F-test & Levene's & \\
\hline $\begin{array}{l}\text { The mass customization lecture helped me to develop a better understanding of } \\
\text { mass customization. }\end{array}$ & 6.00 & 5.67 & 0.528 & 0.493 & 0.160 \\
\hline $\begin{array}{l}\text { The mass customization demonstration of the Timbuk } 2 \text { bag helped me to } \\
\text { develop a better understanding of mass customization. }\end{array}$ & 5.43 & 5.63 & 0.669 & 0.393 & 0.549 \\
\hline $\begin{array}{l}\text { My groups' mass customization report helped me to develop a better } \\
\text { understanding of mass customization. }\end{array}$ & 6.29 & 5.98 & 0.413 & 0.510 & 0.181 \\
\hline $\begin{array}{l}\text { My groups' mass customization presentation helped me to develop a better } \\
\text { understanding of mass customization. }\end{array}$ & 6.11 & 5.86 & 0.619 & 0.712 & 0.330 \\
\hline $\begin{array}{l}\text { The mass customization presentations by other groups in the class helped me to } \\
\text { develop a better understanding of mass customization. }\end{array}$ & 5.75 & 5.80 & 0.592 & 0.443 & 0.869 \\
\hline $\begin{array}{l}\text { The lecture, demonstration, report, and class presentations helped me to develop } \\
\text { a better understanding of: }\end{array}$ & -- & --- & --- & --- & --- \\
\hline mass customization. & 6.14 & 5.88 & 0.839 & 0.561 & 0.220 \\
\hline the overall importance of technology in a mass customization strategy. & 6.00 & 6.10 & $\mathbf{0 . 0 2 5}$ & 0.031 & $* 0.729$ \\
\hline $\begin{array}{l}\text { the importance of the ease of use of technology during the mass customization } \\
\text { steps in a mass customization strategy. }\end{array}$ & 6.00 & 6.04 & $\mathbf{0 . 0 3 8}$ & 0.011 & $* 0.882$ \\
\hline the importance of marketing in a mass customization strategy. & 5.71 & 5.63 & 0.203 & 0.901 & 0.749 \\
\hline the importance of product design in a mass customization strategy. & 5.95 & 5.98 & 0.434 & 0.541 & 0.901 \\
\hline the importance of process design in a mass customization strategy. & 6.00 & 5.94 & 0.816 & 0.763 & 0.801 \\
\hline the importance of scheduling in a mass customization strategy. & 6.05 & 5.82 & 0.744 & 0.579 & 0.372 \\
\hline the importance of inventory management in a mass customization strategy. & 5.95 & 6.14 & 0.011 & $\mathbf{0 . 0 5 0}$ & $* 0.547$ \\
\hline the importance of supply chain management in a mass customization strategy. & 6.05 & 6.02 & 0.239 & 0.482 & 0.924 \\
\hline $\begin{array}{l}\text { the importance of a mass customization strategy in helping a firm attain a } \\
\text { competitive advantage. }\end{array}$ & 6.05 & 5.98 & 0.887 & 0.812 & 0.795 \\
\hline $\begin{array}{l}\text { The mass customization Timbuk2 demonstration was an experiential (active } \\
\text { learning) approach to learning. }\end{array}$ & 5.62 & 5.96 & 0.194 & 0.219 & 0.242 \\
\hline $\begin{array}{l}\text { The mass customization assignment was an experiential (active learning) } \\
\text { approach to learning. }\end{array}$ & 6.05 & 6.02 & 0.742 & 0.781 & 0.912 \\
\hline
\end{tabular}

*2-sample t-test did not use pooled variances 


\section{Appendix 1 Mass Customization Assignment}

Pick a product that you can order on the web such that you have many possible ways to customize the product to your exact specifications. In order to qualify for the assignment, the product must have at least five features that can be customized and each feature must have several options. Product selection will be first-come first served so e-mail me your preferred product and an alternate product.

\section{Grading}

The presentation and the report are each worth $5 \%$ of your grade - total is $10 \%$.

Due Date

The presentation and the report are due in-class during the scheduled final exam period.

\section{Presentation}

Demonstrate to the class how you would configure and order your product from the company web site. As part of your presentation, keep track of the options available and the choices within those options. How many possible combinations are possible? Also, discuss the ease of use of the web site to order the product. Point out any FAQ links or where in the customization process FAQ's would be helpful. Calculate the price of the product (including shipping cost), compare the price to a store-bought or web-purchased product of similar quality and discuss the value proposition to the customer. Discuss the challenges associated with the product including product design, process design and scheduling, inventory management, supply chain management, and marketing. You are strongly encouraged to conduct additional research on your company, competitors and or the industry. This can include library research and contacting the company. Plan on a 20 minute presentation and 5 minutes for questions.

\section{Written Report}

Summarize your presentation in a report of between 5 to 10 double-spaced pages. You may include appendices with your report. 


\section{Appendix 2 Grading Rubric for the Mass Customization Assignment}

Team:

Product and Web Site:

Presentation $(5 \%)$

Demonstration (10 points each)

Ease of Use of Main Page and Suggestions for Improvements

Ease of Use of the Customization Pages (elicitation, Zipkin 2001)

Ease of Use of the Ordering Process

Value Proposition of Customized Product vs. Non-Customized or Store Bought Product Number of Options Tracking

Discussion (10 points each)

Product Design

Process Design and Scheduling

Inventory Management

Supply Chain Management

Marketing and Competitors

Written Report (5\%)

Organization \& Flow (20 points)

Content (50 points)

Product Design

Process Design and Scheduling

Inventory Management

Supply Chain Management

Marketing and Competitors

Additional Research (10 points)

Calculations (10 points)

Formatting and Fatal Flaws (10 points) 


\title{
Appendix 3 Pedagogical Assessment Survey of the Mass Customization Assignment
}

\author{
Gender: Male [ ] Female [ ] Are you an International Student: Yes [ ] No [ ]
}

Learning Objectives: The below questions are concerned with the learning objectives of the mass customization assignment. Please indicate your level of agreement using the following scale. Scale: $1=$ strongly disagree; $4=$ neither agree nor disagree; $7=$ strongly agree

\begin{tabular}{|c|c|c|c|c|c|c|c|}
\hline & \multicolumn{3}{|c|}{$\begin{array}{l}\text { Strongly } \\
\text { disagree }\end{array}$} & & \multicolumn{3}{|c|}{$\begin{array}{r}\text { Strongly } \\
\text { agree }\end{array}$} \\
\hline $\begin{array}{l}\text { The mass customization lecture helped me to develop a better } \\
\text { understanding of mass customization. }\end{array}$ & 1 & 2 & 3 & 4 & 5 & 6 & 7 \\
\hline $\begin{array}{l}\text { The mass customization demonstration of the Timbuk } 2 \text { bag helped me to } \\
\text { develop a better understanding of mass customization. }\end{array}$ & 1 & 2 & 3 & 4 & 5 & 6 & 7 \\
\hline $\begin{array}{l}\text { My groups' mass customization report helped me to develop a better } \\
\text { understanding of mass customization. }\end{array}$ & 1 & 2 & 3 & 4 & 5 & 6 & 7 \\
\hline $\begin{array}{l}\text { My groups' mass customization presentation helped me to develop a better } \\
\text { understanding of mass customization. }\end{array}$ & 1 & 2 & 3 & 4 & 5 & 6 & 7 \\
\hline $\begin{array}{l}\text { The mass customization presentations by other groups in the class helped } \\
\text { me to develop a better understanding of mass customization. }\end{array}$ & 1 & 2 & 3 & 4 & 5 & 6 & 7 \\
\hline $\begin{array}{l}\text { The lecture, demonstration, report, and class presentations helped me to } \\
\text { develop a better understanding of: }\end{array}$ & & $\begin{array}{ll}\text { ong } \\
\text { agr }\end{array}$ & & & & tron & \\
\hline mass customization. & 1 & 2 & 3 & 4 & 5 & 6 & 7 \\
\hline the overall importance of technology in a mass customization strategy. & 1 & 2 & 3 & 4 & 5 & 6 & 7 \\
\hline $\begin{array}{l}\text { the importance of the ease of use of technology during the mass } \\
\text { customization steps in a mass customization strategy. }\end{array}$ & 1 & 2 & 3 & 4 & 5 & 6 & 7 \\
\hline the importance of marketing in a mass customization strategy. & 1 & 2 & 3 & 4 & 5 & 6 & 7 \\
\hline the importance of product design in a mass customization strategy. & 1 & 2 & 3 & 4 & 5 & 6 & 7 \\
\hline the importance of process design in a mass customization strategy. & 1 & 2 & 3 & 4 & 5 & 6 & 7 \\
\hline the importance of scheduling in a mass customization strategy. & 1 & 2 & 3 & 4 & 5 & 6 & 7 \\
\hline the importance of inventory management in a mass customization strategy. & 1 & 2 & 3 & 4 & 5 & 6 & 7 \\
\hline $\begin{array}{l}\text { the importance of supply chain management in a mass customization } \\
\text { strategy. }\end{array}$ & 1 & 2 & 3 & 4 & 5 & 6 & 7 \\
\hline $\begin{array}{l}\text { the importance of a mass customization strategy in helping a firm attain a } \\
\text { competitive advantage. }\end{array}$ & 1 & 2 & 3 & 4 & 5 & 6 & 7 \\
\hline $\begin{array}{l}\text { The mass customization Timbuk } 2 \text { demonstration was an experiential (active } \\
\text { learning) approach to learning. }\end{array}$ & 1 & 2 & 3 & 4 & 5 & 6 & 7 \\
\hline $\begin{array}{l}\text { The mass customization assignment was an experiential (active learning) } \\
\text { approach to learning. }\end{array}$ & 1 & 2 & 3 & 4 & 5 & 6 & 7 \\
\hline
\end{tabular}

Open-ended Questions

What were some positive learning aspects of your Mass Customization assignment?

What were some negative learning aspects of your Mass Customization assignment?

How could the Mass Customization assignment be improved? 